\title{
Analisa Kinerja Keuangan PT BTPN Tbk Periode 2015-2019 dengan POJK Nomor 4/POJK.03/2016
}

Financial performance analysis at PT BTPN Tbk for the period 2015-2019 with POJK Number 4/POJK.03/2016

\section{Ega Virgiani}

Program Studi D3 Keuangan dan Perbankan, Politeknik Negeri Bandung

E-mail: egavirgi2699@gmail.com

\section{Dadang Hermawan}

Jurusan Akuntansi, Politeknik Negeri Bandung

E-mail: dadhar09@yahoo.com

\section{Rosma Pakpahan}

Jurusan Akuntansi, Politeknik Negeri Bandung

E-mail: rosma.pakpahan@polban.ac.id

\begin{abstract}
In 2019, PT BTPN Tbk ranked seventh as the bank with the large asset. The purpose of ther esearch is to analyze financial performance at PT BTPN Tbk 2019 that determinate the bealth of the bank. This research used quantitative and secondary data from annual financial report during 2015-2019. Collecting data method is using literature study. This research using descriptive analysis with ratio: Liquidity Ratio (Quick Ratio, Loan to Fund Ratio (LFR) and Loan to Asset(LAR), Solvability Ratio (Return On Asset(ROA), ROE (Return On Equity), Net Interest Margin (NIM) and BOPO) and Rentability Ratio (Debt to Equity Ratio (DER) and Cash Adequacy Ratio (CAR)). The result of research show that financial performance of PT BTPN Tbk period 2015-2019 in good condition.
\end{abstract}

Keywords: financial performance, bealth of bank, liquidity, rentability, solvability

\section{Pendahuluan}

Industri perbankan merupakan salah satu unsur penting dalam sistem perekonomian negara yang terus berkembang. Menurut UU No.7 Tahun 1992, bank berfungsi sebagai penghimpun dana dari masyarakat dan mendistribusikannya kembali dalam bentuk kredit kepada pihak yang membutuhkan. Keseimbangan industri perbankan diperlukan dalam perekonomian, kestabilan perekonomian tidak diukur hanya dari jumlah uang yang beredar juga dilihat jumlah perangkat penyelenggaraan keuangan yaitu bank. Laporan keuangan perusahaan merupakan instrument penting yang digunakan untuk mendapatkan informasi yang berhubungan dengan posisi keuangan dan pencapaian perusahaan. Tingkat Kesehatan bank merupakan suatu sistem peringatan awal atas kinerja bank saat ini dan peluangnya di masa yang akan datang (Thomson, 1991) Tingkat Kesehatan bank sangat menentukan mutu dan proporsi sistem moneter nasional.

Laporan keuangan menyediakan informasi tentang kondisi kesehatan keuangan sehingga berlaku sebagai acuan dalam pengambilan keputusan investor dalam melakukan investasi. Kinerja keuangan menggambarkan kondisi kegiatan operasional suatu perusahaan (Setiawan dkk., 2020). 
Kinerja keuangan dapat diketahui dengan menghitung rasio-rasio keuangan sehingga kinerja keuangan dapat diketahui dengan menggunakan 3 analisis rasio yaitu rasio likuiditas, rentabilitas dan solvabilitas. Analisis rasio merupakan teknik analisis untuk mengetahui hubungan antara pospos dalam neraca maupun laporan rugi laba bank secara individual dan konsilidasi (Munawir, 2004).

PT BTPN Tbk salah satu bank swasta yang terdaftar sebagai 10 perbankan nasional dengan aset terbesar setelah melakukan merger antara PT Bank Tabungan Pensiunan Nasional (BTPN) dengan Sumitomo Mitsui Banking Corporation (SMBC). PT BTPN Tbk merupakan bank yang mayoritas sahamnya dimiliki oleh swasta dan sebagian kecil oleh publik. Berdasarkan data perseroan, peleburan dua bank ini menghasilkan total aset sebesar Rp189,92 triliun per Desember 2019 dan total kredit sebesar Rp141,76 triliun.

Penelitian ini bertujuan untuk mendeskripsikan kinerja keuangan bank berdasarkan hasil analisis rasio keuangan perbankan yaitu rasio likuiditas, rentabilitas dan solvabilitas.

\section{Kajian Pustaka}

\subsection{Bank}

Kasmir (2015), "Bank adalah lembaga keuangan yang kegiatan utamanya adalah menghimpun dana dari masyarakat dan menyalurkan kembali dana tersebut ke masyarakat serta memberikan jasa bank lainnya."

Kuncoro (2000), "Bank adalah institusi keuangan yang kegiatan..utamanya adalah menghimpun dana dan..menyalurkan kembali dana tersebut ke masyarakat dalam bentuk kredit serta memberikan jasa-jasa dalam lalu lintas pembayaran dan peredaran uang"

Abdurahman (1999), "Bank adalah suatu jenis lembaga keuangan yang menjalankan segala macam jasa seperti dengan memberikan pinjaman atau lend, menyalurkan valuta atau circulating currency, kemudian berperan sebagai tempat penyimpanan barang yang bernilai tinggi atau storage of value objects, dan pembiayaan terhadap usaha atau perusahaan lain."

Bank adalah lembaga keuangan yang memiliki dua peran penting yaitu sebagai penyalur dana untuk pihak yang membutuhkan dana dan sebagai penyimpan dana dari masyarakat.

\subsection{Laporan Keuangan}

Raharjaputra (2011), "Laporan keuangan adalah alat yang penting untuk memperoleh informasi sehubungan dengan posisi keuangan dan hasil yang telah dicapai oleh perusahaan tersebut."

Subramanyam (2010), "Laporan keuangan adalah produk proses laporan keuangan yang diatur oleh standar dan aturan akuntansi, intensif manajer, serta mengenai mekanisme pelaksanaan dan juga pengawasan perusahaan"

Laporan keuangan dapat disimpulkan sebagai informasi penting tentang keuangan dan hasil lain yang dicapai oleh perusahaan pada periode tertentu untuk menggambarkan kinerja perusahaan.

\subsection{POJK No.4/POJK.03/2016}

Pada 31 Desember 2013 pengawasan kinerja keuangan sektor perbankan beralih dari Bank Indonesia kepada Otoritas Jasa Keuangan. OJK bertanggung jawab atas pengawasan semua lembaga keuangan mulai dari sektor perbankan maupun non perbankan. Dengan adanya POJK No.4/POJK.03/2016 membuat PBI No.13/1/PBI/2011 tidak berlaku. POJK No.4/POJK.03/2016 memuat peraturan mengenai kinerja bank umum di Indonesia. 


\subsection{Kinerja Keuangan}

Kinerja keuangan adalah gambaran tentang prestasi perusahaan berupa pencapaian yang telah diraih berkat berbagai aktivitas yang sudah dicapai berbagai aktivitas yang telah dilakukan (Fahmi, 2011). Tahapan melakukan kinerja keuangan yaitu:

1. Evaluasi laporan.keuangan apakah sudah sesuai dengan pedoman akuntansi sehingga bisa dipertanggungjawabkan.

2. Melakukan perhitungan dengan menggunakan rasio-rasio.

3. Membandingkan hasil perhitungan setiap tahunnya.

4. Melakukan interpretasi terhadap permasalahan yang ditemukan dalam perhitungan.

5. Mencari dan membuat penyelesaian masalah.

Analisis Kinerja Keuangan bertujuan untuk (Abdullah, 2005):

1) Untuk mengetahui kesuksesan manajemen keuangan bank terutama kondisi likuiditas, solvabilitas dan rentabilitas yang dicapai dalam tahun berjalan maupun tahun terdahulu.

2) Untuk mengetahui kemampuan bank dalam mengefektifkan semua aktiva yang dimiliki dalam menghasilkan keuntungan.

\subsection{Analisis Rasio Keuangan}

Menurut Abdullah (2005) “Analisis Rasio Keuangan merupakan teknik analisis keuangan untuk mengetahui korelasi antara pos-pos tertentu dalam neraca.maupun laporan.laba rugi baik secara individu maupun secara seksama."

Analisis rasio keuangan adalah suatu teknik evaluasi kinerja keuangan perusahaan dalam satu periodik tertentu berdasarkan laporan keuangan perusahaan tersebut.

Menurut (Kasmir, 2012)"Rasio keuangan merupakan aktivitas membandingkan.angka-angka yang ada dalam laporan keuangan dengan cara membagi satu angka dengan angka lainnya. Perbandingan dapat dilakukan antara satu komponen dengan komponen dalam satu laporan keuangan atau antar komponen yang ada di antara laporan keuangan."

Macam-macam rasio keuangan perbankan yang digunakan antara lain:

1. Rasio Likuiditas

a) Quick Ratio (QR)

Rumus dari Quick ratio adalah sebagai berikut (Syahyunan, 2013):

QR $=\frac{\text { Cash Assets }}{\text { Total Deposit }} \times 100 \%$

b) Loan to Fund Ratio (LFR)

Rumus Loan to Fund Ratio adalah sebagai berikut (PBI No.17/11/PBI 2015, 2015):

$\mathrm{LFR}=\frac{\text { Kredit }}{\text { Dana Pihak Ketiga }+ \text { Surat Berharga }} \times 100 \%$

c) Loan to Asset Ratio (LAR)

Rumus Loan to Asset Ratio adalah sebagai berikut (Kasmir, 2012):

$\mathrm{LAR}=\frac{\text { Total } \text { Loans }}{\text { Total } \text { Assets }} \times 100 \%$

2. Rasio Rentabilitas

a) Return On Asset (ROA)

Rumus Return On Asset adalah sebagai berikut (SEBI 13/30/DPNP 16 Desember 2011, 2011):

$\mathrm{ROA}=\frac{\text { Laba Sebelum } \text { Pajak }}{\text { Rata-rata total asset }} \times 100 \%$

b) Return On Equity (ROE)

Rumus Return On Equity adalah sebagai berikut (SEBI 13/30/DPNP 16 Desember 2011, 2011): 


$$
\mathrm{ROE}=\frac{\text { Laba Setelah Pajak }}{\text { Rata-rata ekuitas }} \times 100 \%
$$

c) Net Interest Margin (NIM)

Rumus Net Interest Margin adalah sebagai berikut (SEBI 13/24/DPNP/2011, 2011):

$$
\mathrm{NIM}=\frac{\text { Pendapatan Bunga Bersih }}{\text { Rata- } \text { Rata Aset Produktif }} \times 100 \%
$$

d) $\mathrm{BOPO}$

Rumus BOPO adalah sebagai berikut (SEBI 13/30/DPNP 16 Desember 2011, 2011):

3. Rasio Solvabilitas

$$
\mathrm{BOPO}=\frac{\text { Total Beban Operasional }}{\text { Total Pendapatan Operasional }} \times 100 \%
$$

a) Cash Adequacy Ratio (CAR)

Rumus Cash Adequacy Ratio yaitu (Kasmir, 2012):

$$
\mathrm{CAR}=\frac{\text { Modal }}{\text { ATMR }} X 100 \%
$$

b) Debt to Equity Ratio (DER)

Rumus dari Debt to Equity Ratio yaitu sebagai berikut (Dendawijaya, 2005):

$$
\mathrm{DER}=\frac{\text { Jumlah Hutang }}{\text { Jumlah Modal Sendiri }} \times 100 \%
$$

\section{Metode Penelitian}

Jenis penelitian yang digunakan dalam penelitian ini adalah analisis deskriptif, menurut Sugiyono (2016) "Penelitian deskriptif adalah penelitian yang dilaksanakan untuk memahami nilai variabel mandiri, baik satu variabel atau lebih (independen) tanpa membuat perbandingan atau menyambungkan antsara satu variabel dan variabel lainnya" Analisis deskriptif ini bertujuan untuk menghasilkan deskripsi, pemaparan atau narasi secara terstruktur, benar, dan saksama mengenai sifat-sifat serta korelasi antar fenomena yang diteliti."

Fokus penelitian dalam penelitian ini adalah:

1. Laporan Keuangan.Tahunan BTPN Tbk.Periode 2015-2019 yang mencakup neraca, laporan laba rugi dan.catatan atas laporan.keuangan.

2. Analisis rasio keuangan bank yang cocok dan berhubungan dengan regulasi perbankan Indonesia terdiri dari: Rasio Likuiditas (Quick Ratio, Loan to Fund Ratio, dan Loan.to Asset Ratio), Rasio.Rentabilitas (Return On Asset, Return On Equity, Net Interest Margin dan BOPO), Rasio Solvabilitas (Cash Adequacy Ratio dan Debt to Equity Ratio).

Berikut adalah rincian tahap-tahap dalam analisis data:

1. Ulas data keuangan dari laporan keuangan tahunan yang berkaitan dengan PT BTPN Tbk pada tahun 2015-2019. Bagian laporan yang digunakan adalah neraca, laporan laba rugi dan catatan atas laporan keuangan.

2. Pengkalkulasian rasio.likuiditas, rentabilitas dan solvabilitas pada..laporan keuangan bank.yang mencakup:

a) Rasio Likuiditas

1) Quick Ratio

2) Loan to Fund Ratio

3) Loan to Asset Ratio

b) Rasio Rentabilitas

1) Return On Asset

2) Return On Equity 


\section{3) Net Interest Margin}

4) $\mathrm{BOPO}$

c) Rasio Solvabilitas

1) Cash Adequacy Ratio

2) Debt to Equity Ratio

3. Dengan metode time series analysis, lakukan perbandingan hasil kalkulasi rasio keuangan setiap tahun

4. Menafsirkan nilai rasio yang telah dikalkulasi dan membandingkannya dengan tolak ukur peringkat komposit Otoritas Jasa Keuangan untuk menghitung kinerja keuangan PT BTPN Tbk.

\section{Hasil dan Pembahasan}

4.1 Rasio Likuiditas

a) Quick Ratio

Tabel 1 Quick Ratio

\begin{tabular}{|c|c|c|c|c|}
\hline Tahun & Cash Asset & Total Deposit & $\begin{array}{c}\text { Quick } \\
\text { Ratio }\end{array}$ & PK \\
\hline 2015 & Rp6.193.497.000.000 & Rp57.475.178.000.000 & 10,78 & 2(Sehat) \\
\hline 2016 & Rp6.931.967.000.000 & Rp62.721.333.000.000 & 11,05 & 2(Sehat) \\
\hline 2017 & Rp7.083.068.000.000 & Rp63.492.609.000.000 & 11,16 & 2(Sehat) \\
\hline 2018 & Rp7.928.244.000.000 & Rp64.866.246.000.000 & 12,22 & 2(Sehat) \\
\hline 2019 & Rp12.343.045.000.000 & Rp91.022.289.000.000 & 13,56 & 2(Sehat) \\
\hline
\end{tabular}

Quick ratio adalah rasio antara aset lancar dengan hutang lancar. Quick ratio menunjukan kemampuan bank memenuhi hutangnya dengan menggunakan aset lancar. Perkembangan quick ratio pada tahun 2015 sehingga 2019 angka quick ratio mengalami kenaikan. Angka 10,78\% pada tahun 2015 menunjukan bahwa bank memiliki kemampuan untuk memenuhi sebesar 10,78\% menggunakan cash asset dari total deposit yang disimpan deposan pada tahun 2015. Begitu juga dengan tahun-tahun selanjutnya.

Pada tahun 2016 terjadi kenaikan angka quick ratio sebesar 0,27\% menjadi 11,05\%. Peningkat tersebut disebabkan karena kenaikan cash asset menjadi Rp6.193.497.000.000 dibanding 2015, sementara itu total deposit juga mengalami peningkatan menjadi sebesar Rp62.721.333.000.000 dibandingkan pada tahun 2019. Peningkatan yang signifikan terjadi pada tahun 2019 yaitu sebesar 1,34\% menjadi 13,56\%. Peningkatan tersebut disebabkan karena pada tahun 2019 terjadi peningkatan total deposit menjadi Rp91.022.289.000.000 dari Rp64.866.246.000.000 dan cash assets Rp12.343.045.000.0000.

b) Loan to Fund Ratio

Tabel 2 Loan to Fund Ratio

\begin{tabular}{|c|c|c|c|c|}
\hline Tahun & Kredit & DPK+SB & LFR & PK \\
\hline 2015 & Rp58.587.383.000.000 & Rp65,203,464,000,000 & $89.85 \%$ & 3 (Cukup Sehat) \\
\hline 2016 & Rp63.168.410.000.000 & Rp72,154,070,000,000 & $87.55 \%$ & 3 (Cukup Sehat) \\
\hline 2017 & Rp65.351.837.000.000 & Rp74,284,615,000,000 & $87.97 \%$ & 3 (Cukup Sehat) \\
\hline 2018 & Rp68.136.780.000.000 & Rp77,711,218,000,000 & $87.68 \%$ & 3 (Cukup Sehat) \\
\hline 2019 & Rp141.760.183.000.000 & Rp97,642,330,000,000 & $145.18 \%$ & 5 (Tidak Sehat) \\
\hline
\end{tabular}

Loan to Fund Ratio adalah rasio yang menunjukan tingkat kredit yang disalurkan oleh bank dan jumlah penerimaan dana dari pihak ketiga dan surat berharga yang dimiliki. Semakin tinggi tingkat LFR maka semakin banyak dana pihak ketiga yang dialirkan menjadi kredit sehingga resiko bank menjadi meningkat. Angka 89,55\% pada LFR menunjukan bahwa untuk memenuhi kredit bank menggunakan 89,55\% dari dana pihak ketiga dan surat berharga. Begitupun angka pada tahun-tahun berikutnya. 
Pada tahun 2019 terjadi kenaikan tingkat LFR secara drastis sebesar 57,5\% menjadi 145,18\% yang disebabkan oleh kenaikan kredit menjadi Rp141.760.183.000.000 dari Rp68.136.789.000.000 terhadap kenaikan Dana Pihak Ketiga dan Surat Berharga menjadi 97.642.330.000.000 dari tahun sebelumnya. Hal ini juga menyebabkan menurunnya peringkat komposit dari peringkat 3 ke peringkat 5 dengan predikat tidak sehat.

c) Loan to Asset Ratio

Tabel 3 Loan to Asset Ratio

\begin{tabular}{|c|c|c|c|c|}
\hline Tahun & Kredit & Total Asset & LAR & PK \\
\hline 2015 & Rp58.587.383.000.000 & Rp81.039.663.000.000 & $72,29 \%$ & 1 (Sangat sehat) \\
\hline 2016 & Rp63.168.410.000.000 & Rp91.371.387.000.000 & $69,13 \%$ & 1 (Sangat sehat) \\
\hline 2017 & Rp65.351.837.000.000 & Rp95.489.850.000.000 & $68,44 \%$ & 1 (Sangat sehat) \\
\hline 2018 & Rp68.136.780.000.000 & Rp101.341.224.000.000 & $67,24 \%$ & 1 (Sangat sehat) \\
\hline 2019 & Rp141.760.183.000.000 & Rp181.631.385.000.000 & $78,05 \%$ & 2 (Sehat) \\
\hline
\end{tabular}

Loan to Asset Ratio adalah rasio yang menunjukan kapasitas aset bank untuk memenuhi kredit. Semakin besar LAR maka menunjukan bank semakin tidak likuid karena bank membutuhkan aset yang banyak untuk memenuhi tingkat kredit yang dibutuhkan oleh debitur. Angka 72,29\% pada LAR menunjukan bahwa untuk memenuhi kredit bank membutuhkan 72,29\% dari asset yang dimilikinya. Begitupun angka pada tahun berikutnya.

Pada tahun 2016, terjadi penurunan LAR menjadi 69,13\% yang disebabkan oleh kenaikan kredit sebesar 7,78\% menjadi Rp63.168.410.000.000 dan kenaikan kredit sebesar 12,74\% menjadi Rp91.371.387.000.000 kenaikan kredit dan total asset yang seimbang menyebabkan terjadinya penurunan tingkat LAR.

Pada tahun 2019 terjadi kenaikan tingkat LAR yang signifikan sebesar 10,81\% yang menyebabkan terjadinya penurunan peringkat komposit dari 1 ke peringkat 2 dengan predikat Sehat. Hal ini disebabkan oleh kenaikan total asset dan kredit secara signifikan akibat terjadinya merger.

\subsection{Rasio Rentabilitas}

a) Return On Asset

Tabel 4 Return On Asset

\begin{tabular}{|c|c|c|c|l|}
\hline Tahun & Laba Sebelum Pajak & Total Asset & RO $A$ & \multicolumn{1}{|c|}{ PK } \\
\hline 2015 & $\mathrm{Rp} 2.432 .611 .000 .000$ & $\mathrm{Rp} 81.039 .663 .000 .000$ & 3,00 & PK 1 (Sangat sehat) \\
\hline 2016 & $\mathrm{Rp} 2.604 .519 .000 .000$ & $\mathrm{Rp} 91.371 .387 .000 .000$ & 2,85 & PK 1 (Sangat sehat) \\
\hline 2017 & $\mathrm{Rp} 1.936 .845 .000 .000$ & $\mathrm{Rp} 95.489 .850 .000 .000$ & 2,03 & PK 1 (Sangat sehat) \\
\hline 2018 & $\mathrm{Rp} 2.919 .248 .000 .000$ & $\mathrm{Rp} 101.341 .224 .000 .000$ & 2,88 & PK 1 (Sangat sehat) \\
\hline 2019 & $\mathrm{Rp} 4.018 .922 .000 .000$ & $\mathrm{Rp} 181.631 .385 .000 .000$ & 1,65 & PK 2 (Sehat) \\
\hline
\end{tabular}

Return On Asset adalah rasio antara laba sebelum pajak dan total asset. ROA menunjukan keahlian bank menghasilkan laba dari aset yang dipunyai. Semakin tinggi ROA maka semakin baik profitabilitas suatu bank dan juga menunjukan semakin baiknya kinerja keuangan bank. Angka ROA 2015 sebesar 3\%, menunjukan kemampuan perusahaan menghasilkan laba sebesar 3\% lipat dari total asset yang dimilikinya.

Pada tahun 2019 terjadi angka ROA terendah pada periode 2015-2019 yaitu sebesar 1,65\%. Hal ini disebabkan ketidakseimbangan antara kenaikan laba sebelum pajak sebesar $37,66 \%$ dan total asset sebesar 79,22\% sehingga penurunan tingkat ROA terjadi secara signifikan. Hasil perhitungan ini menginterpretasikan bahwa perusahaan kehilangan kemampuannya mendapatkan laba secara signifikan.

b) Return On Equity 
Tabel 5 Return On Equity

\begin{tabular}{|c|c|c|c|c|}
\hline Tahun & Laba Setelah Pajak & Total Ekuitas & ROE & PK \\
\hline 2015 & Rp1.752.609.000.000 & Rp13.923.859.000.000 & 12,59 & PK 2 (Sehat) \\
\hline 2016 & Rp1.875.846.000.000 & Rp16.312.428.000.000 & 11,50 & PK 3 (Cukup sehat) \\
\hline 2017 & Rp1.421.940.000.000 & Rp17.200.797.000.000 & 8,27 & PK 3 (Cukup sehat) \\
\hline 2018 & $\mathrm{Rp} 2.128 .054 .000 .000$ & $\mathrm{Rp} 18.786 .330 .000 .000$ & 11,33 & PK 3 (Cukup sehat) \\
\hline 2019 & $\mathrm{Rp} 2.992 .418 .000 .000$ & $\mathrm{Rp} 31.471 .928 .000 .000$ & 9,51 & PK 3 (Cukup sehat) \\
\hline
\end{tabular}

Return On Equity adalah rasio antara laba setelah pajak dan total ekuitas. ROE menunjukan kemampuan bank menghasilkan laba dari penggunaan ekuitas yang dimiliki. Semakin tinggi ROE maka semakin efektiF penggunaan ekuitas pada bank. Angka ROE pada tahun 2015 terbesar di periode 2015-2019 dengan angka 12,59\%, hal ini menunjukan bahwa laba setelah pajak dihasilkan dari penggunaan ekuitas sebesar 12,59\%. Berikut pada tahun-tahun berikutnya.

Pada tahun 2017 menyentuh angka terendah yaitu sebesar 8,27\% yang disebabkan oleh depresiasi laba setelah pajak dari Rp1.875.846.000.000 menjadi Rp1.421.940.000.000 dan kenaikan total ekuitas sebesar 5,45\% menjadi Rp17.200.797.000.000 sehingga tingkat ROE menurun dan ada di peringkat komposit 3 dengan prediksi cukup sehat.

c) Net Interest Margin

Tabel 5 Net Interest Margin

\begin{tabular}{|c|c|r|r|c|}
\hline Tahun & $\begin{array}{c}\text { Pendapatan Bunga } \\
\text { Bersih }\end{array}$ & Rata Rata Aset Produktif & NIM & PK \\
\hline 2015 & Rp7.695.611.000.000 & Rp66.386.208.000.000 & 11,59 & PK 1 (Sangat sehat) \\
\hline 2016 & Rp8.853.979.000.000 & Rp73.761.318.000.000 & 12,00 & PK 1 (Sangat sehat) \\
\hline 2017 & Rp9.521.610.000.000 & Rp75.170.357.000.000 & 12,67 & PK 1 (Sangat sehat) \\
\hline 2018 & Rp9.600.408.000.000 & Rp79.856.343.000.000 & 12,02 & PK 1 (Sangat sehat) \\
\hline 2019 & Rp11.047.764.000.000 & Rp160.738.785.000.000 & 6,87 & PK 1 (Sangat sehat) \\
\hline
\end{tabular}

Net Interest Margin adalah rasio antara perolehan bunga bersih dan rata-rata aset produktif. Rasio NIM menunjukan kemampuan bank untuk mengelola aset produktifnya untuk mendapatkan pendapatan bersih. Semakin tinggi NIM maka semakin tinggi juga pendapatan yang dihasilkan oleh bank. Angka NIM pada tahun 2015 sebesar 11,59\% menginterpretasikan bahwa pendapatan bunga bersih yang dihasilkan merupakan 11,59\% dari rata-rata aset produktif. Begitupun dengan angka pada tahun berikutnya.

Pada tahun 2017, NIM mencapai tingkat tertinggi pada periode 2015-2019 dengan pendapatan bunga bersih sebesar Rp9.521.610.000.000 dan rata-rata aset produktif sebesar Rp75.170.357.000.000. Dan pada tahun 2019 terjadi penurunan tingkat NIM sebesar 5,15\% dari $12,02 \%$ menjadi $6,87 \%$, hal ini disebabkan oleh tidak imbangnya kenaikan rata-rata aset produktif sebesar 101\% menjadi Rp160.738.785.000.000 bila dibandingkan kenaikan pendapatan bunga bersih sebesar 15,07\% dari Rp9.600.408 menjadi Rp11.047.764.000.000.

d) $\mathrm{BOPO}$

Tabel 7 BOPO

\begin{tabular}{|c|c|c|c|c|}
\hline Tahun & Beban Operasional & Pendapatan Operasional & BOPO & PK \\
\hline 2015 & Rp7.695.611.000.000 & Rp13,709,711,000,000 & 82,06 & PK 1 (Sangat sehat) \\
\hline 2016 & Rp8.853.979.000.000 & Rp14,384,277,000,000 & 63,73 & PK 1 (Sangat sehat) \\
\hline 2017 & Rp9.521.610.000.000 & Rp14,686,057,000,000 & 65,86 & PK 1 (Sangat sehat) \\
\hline 2018 & Rp9.600.408.000.000 & Rp14,911,012,000,000 & 60,94 & PK 1 (Sangat sehat) \\
\hline 2019 & Rp11.047.764.000.000 & Rp20,644,949,000,000 & 63,31 & PK 1 (Sangat sehat) \\
\hline
\end{tabular}

BOPO adalah rasio antara beban operasional dan pendapatan operasional. BOPO menunjukan tingkat efisiensi dan juga kemampuan bank dalam..melakukan kegiatan operasionalnya. Semakin.rendah tingkat BOPO maka semakin efisien kegiatan operasional suatu bank. Angka BOPO pada tahun 2015 sebesar 82,06\% menunjukan bahwa 82,06\% dari pendapatan operasional harus menutupi biaya beban operasional bank. Begitupun 
tahun-tahun berikutnya.

Pada tahun 2018, BOPO mencapai tingkat tertinggi sebesar 60,94\% yang disebabkan kenaikan beban operasional sebesar 0,82\% menjadi Rp9.600.408.000.000 dan pendapatan operasional sebesar 1,53\% menjadi Rp14.911.012.000.000 yang berarti bank hanya harus mengeluarkan $60,94 \%$ untuk menutupi beban operasionalnya.

\subsection{Solvabilitas}

a) Cash Adequacy Ratio (CAR)

Tabel 8 Cash Adequacy Ratio

\begin{tabular}{|c|c|cc|c|c|}
\hline Tahun & Ekuitas & ATMR & CAR & PK \\
\hline 2015 & $\mathrm{Rp} 13.923 .859 .000 .000$ & $\mathrm{Rp}$ & 50.488 .124 .000 .000 & 27,58 & PK 1 (Sangat sehat) \\
\hline 2016 & $\mathrm{R} 16.312 .428 .000 .000$ & $\mathrm{Rp}$ & 54.757 .564 .000 .000 & 29,79 & PK 1 (Sangat sehat) \\
\hline 2017 & $\mathrm{R} 17.200 .797 .000 .000$ & $\mathrm{Rp}$ & 56.603 .436 .000 .000 & 30,39 & PK 1 (Sangat sehat) \\
\hline 2018 & $\mathrm{R} 18.786 .330 .000 .000$ & $\mathrm{Rp}$ & 58.240 .752 .000 .000 & 32,26 & PK 1 (Sangat sehat) \\
\hline 2019 & $\mathrm{R} 31.471 .928 .000 .000$ & $\mathrm{Rp}$ & 131.813 .922 .000 .000 & 23,88 & PK 1 (Sangat sehat) \\
\hline
\end{tabular}

Cash Adequacy Ratio adalah rasio perbandingan antara ekuitas dan aktiva tertimbang menurut resiko (ATMR). CAR menunjukan kemampuan bank dalam penyediaan dana yang digunakan untuk mengatasi resiko kerugian. Batas aman untuk CAR adalah 8\% semakin tinggi tingkat CAR maka semakin bagus kemahiran bank dalam mengatasi kerugian. Pada CAR tahun 2018 menunjukan angka 27,58\% menunjukan bahwa bank dapat memenuhi resiko kerugian sebesar $27,58 \%$ dengan menggunakan ekuitasnya.

Pada tahun 2019, terjadi tingkat CAR terendah sebesar 23,88\% yaitu terjadi penurunan sebesar 8,38\% dari tahun sebelumnya. Hal ini disebabkan kenaikan ekuitas sebesar 67,52\% dari Rp18.786.330.000.000 menjadi Rp31.471.928.000.000 dan kenaikan ATMR sebesar Rp73.573.170.000 menjadi Rp131.813.922.000.000. Hal ini menunjukan bahwa bank mengalami penurunan kemampuannya untuk memenuhi resiko kerugian tetapi masih dalam batas yang normal.

b) Debt to Equity Ratio

Tabel 9. Debt to Equity

\begin{tabular}{|c|c|c|c|}
\hline Tahun & Total Hutang & Modal & $\begin{array}{c}\text { Debt to Equity } \\
\text { Ratio }\end{array}$ \\
\hline 2015 & $\mathrm{Rp} 64.053 .233 .000 .000$ & $\mathrm{Rp} 13.923 .859 .000 .000$ & $460,03 \%$ \\
\hline 2016 & $\mathrm{Rp} 70.664 .245 .000 .000$ & $\mathrm{Rp} 16.312 .428 .000 .000$ & $433,19 \%$ \\
\hline 2017 & $\mathrm{Rp} 73.041 .005 .000 .000$ & $\mathrm{Rp} 17.200 .797 .000 .000$ & $424,64 \%$ \\
\hline 2018 & $\mathrm{Rp} 76.562 .034 .000 .000$ & $\mathrm{Rp} 18.786 .330 .000 .000$ & $407,54 \%$ \\
\hline 2019 & $\mathrm{Rp} 142.608 .793 .000 .000$ & $\mathrm{Rp} 31.471 .928 .000 .000$ & $453,13 \%$ \\
\hline
\end{tabular}

Debt to Equity ratio adalah rasio antara hutang dan modal sendiri. DER menunjukkan seberapa besar tingkat utang perusahaan terhadap modalnya. DER yang tinggi pada sebuah bank menunjukan seberapa besar jumlah dana pihak ketiga (DPK) yang disimpan nasabah, maka semakin banyak dana yang disalurkan dalam bentuk kredit. DER tahun 2015 menunjukan angka 460,03\% yang berarti bahwa dari Rp1 modal yang dimiliki sebanding dengan Rp460 hutang yang dimiliki oleh perusahaan.

Pada tahun 2015 hingga tahun 2018 terjadi penurunan tingkat DER namun pada tahun 2019 terjadi kenaikan DER menjadi 453,13\% yang disebabkan oleh naiknya total hutang sebesar Rp66.046.759.000.000 menjadi Rp142.608.793.000.000 dan naiknya modal sebesar Rp12.685.598.000.000 menjadi Rp31.471.928.000.000.

2.4 Analisis Keseluruhan

Tabel 10 Analisis Keseluruhan 
Ega Virgiani, Dadang Hermawan, Rosma Pakpahan

\begin{tabular}{|l|l|l|l|l|l|}
\hline & 2015 & 2016 & 2017 & 2018 & 2019 \\
\hline Quick Ratio & $10,78 \%$ & $11,05 \%$ & $11,16 \%$ & $12,22 \%$ & $13,56 \%$ \\
\hline Loan to Fund Ratio & $89,85 \%$ & $87,55 \%$ & $87,97 \%$ & $87,68 \%$ & $145,18 \%$ \\
\hline Loan to Asset Ratio & $72,29 \%$ & $69,13 \%$ & $68,44 \%$ & $67,24 \%$ & $78,05 \%$ \\
\hline Return On Asset & $3,00 \%$ & $2,85 \%$ & $2,03 \%$ & $2,88 \%$ & $2,21 \%$ \\
\hline Return On Equity & $12,59 \%$ & $11,50 \%$ & $8,27 \%$ & $11,33 \%$ & $9,51 \%$ \\
\hline Net Interest Margin & $11,59 \%$ & $12,00 \%$ & $12,67 \%$ & $12,02 \%$ & $6,87 \%$ \\
\hline BOPO & $82,06 \%$ & $63,73 \%$ & $65,86 \%$ & $60,94 \%$ & $63,31 \%$ \\
\hline Cash Adequacy Ratio & $23,88 \%$ & $32,26 \%$ & $30,39 \%$ & $29,79 \%$ & $27,58 \%$ \\
\hline Debt to Equity Ratio & $460,03 \%$ & $433,19 \%$ & $424,64 \%$ & $407,54 \%$ & $453,13 \%$ \\
\hline
\end{tabular}

Berdasarkan hasil analisis diatas menunjukan bahwa kinerja keuangan PT Bank BTPN Tbk dalam kondisi sehat. Dari aspek liquiditas, quick ratio mengalami penurunan dari tahun 2015 s.d 2019 hal ini disebabkan oleh kenaikan simpanan dana pihak ketiga. Pada Loan to Fund Ratio dan Loan to Asset Ratio terjadi penurunan kualitas pada tahun 2019 hal ini terjadi karena terjadi kenaikan pada kredit yang berasal dari hasil merger dengan PT Bank Sumitomo Mitsui Indonesia (SMBCI), hal ini menyebabkan LFR berada dibawah batas aman 110\% yaitu mencapai angka 163,06\%.

Pada aspek rentabilitas, Return On Asset mengalami fluktuatif pada tahun 2018 meningkat yang disebabkan oleh peningkatan pendapatan bunga, pendapatan operasional dan efisiensi beban operasional. Pada 2019 terjadi penurunan kembali dikarenakan kenaikan total aset yang kontras dengan kenaikan pendapatan sebelum pajak. Return On Asset selama 5 tahun berada pada peringkat komposit 1 dengan predikat Sangat Sehat. Return On Equity mengalami penurunan sejak 2015 sampai 2017 dan meningkat di 2018 yang disebabkan peningkatan saham, tambahan modal dan saldo laba. Return On Equity pada tahun 2015 berada pada peringkat komposit 2 dengan predikat Sehat, tetapi pada tahun 2016 hingga 2019 turun dan berada pada peringkat komposit 3 dengan predikat cukup sehat. Net Interest Margin mengalami fluktuasi dan mengalami penurunan signifikan pada tahun 2019 yang disebabkan oleh peningkatan aset produktif berupa kredit, giro, penyertaan dan saham-saham. Net Interest Margin selama 5 tahun berada pada peringkat komposit 1 dengan predikat Sangat Sehat. BOPO mengalami fluktuasi tetapi tetap ada pada Peringkat Komposit 1 dengan predikat sangat sehat. Pada tahun 2019 terjadi kenaikan beban operasional yang disebabkan oleh peningkatan beban bunga, CKPN, dan beban operasional lainnya. Kenaikan beban operasional juga diiringi oleh kenaikan pendapatan operasional yang disebabkan oleh pendapatan bunga dan pendapatan operasional lainnya.

Pada aspek solvabilitas, Cash Adequacy Ratio selama 5 tahun berada pada Peringkat Komposit 1ldenganlpredikatlsangat sehat. CAR terendah ditunjukan pada tahun 2015 dengan angka 23,88\%. Penurunan Debt to Equity Ratio dari tahun 2015 hingga tahun 2018 disebabkan oleh ketimpangan kenaikan antara hutang dengan kenaikan modal. Pada tahun 2019, DER memiliki selisih tipis dengan DER tertinggi yang ditunjukan pada tahun 2015. Hutang pada tahun 2019 disebabkan oleh meningkatnya Dana Pihak Ketiga.

\section{Penutup}

\subsection{Kesimpulan}

Dari hasil penelitian dapat disimpulkan bahwa:

1. Aspek Likuiditas pada tahun 2015-2019 berada pada kondisi sehat. Pada tahun 2019 terjadi kenaikan tingkat LFR melebihi batas aman 110\% yang disebabkan oleh kenaikan kredit sebesar 108\% yang disebabkan oleh merger pada Februari 2019.

2. Aspek Rentabilitas pada tahun 2015-2019 berada pada kondisi Sehat. PT Bank BTPN Tbk dapat mengelola sumber pendapatan bank dengan baik walaupun 
terjadi fluktuasi laba perusahaan dan pada tahun 2013 terjadi penurunan laba perusahaan yang disebabkan oleh peningkatan beban operasional dan pembentukan penyisihan kerugian aset produktif.

3. Aspek Solvabilitas pada tahun 2015-2019 berada kondisi Sehat. PT Bank BTPN Tbk selama 2015-2019 mengalami penurunan tingkat CAR tetapi dalam peringkat yang sehat.

\subsection{Saran}

Dari hasil penelitian yang dilakukan maka saran yang dapat diberikan adalah:

1. PT Bank BTPN Tbk sebaiknya meningkatkan dana pihak ketiga agar tingkat likuiditas menjadi lebih tinggi sehingga likuiditas bank bisa lebih baik. Untuk mendapat tingkat likuiditas yang aman yaitu sebesar 110\%, pihak bank dapat menaikan Dana Pihak Ketiga sebesar 32\% menjadi Rp128.887.875.600.000.

2. Meski tingkat BOPO sudah baik tetapi beban-beban operasional sebaiknya ditekan sehingga laba perusahaan dapat meningkat.

3. Pertumbuhan hutang pada rasio solvabilitas dapat dibarengi dengan penambahan modal sehingga rasio DER dan CAR dapat terjaga dengan baik.

\section{Daftar Pustaka}

A.Abdurahman. (1999). Ensiklopedia Ekonomi Keuangan Perdagangan. Pradnya Paramita.

Abdullah, M. F. (2005). Dasar-Dasar Manajemen Kenangan. Penerbitan Universitas Muhammadiyah.

SEBI 13/24/DPNP/2011, (2011).

SEBI 13/30/DPNP 16 Desember 2011, (2011).

PBI No.17/11/PBI 2015, (2015).

Dendawijaya, L. (2005). Manajemen Perbankan. Ghalia Indonesia.

Fahmi, I. (2011). Analisis Laporan Keuangan (CV Alfabet).

Kasmir. (2012). Analisis Laporan Keuangan. Rajagrafindo Persada.

Kasmir. (2015). Bank dan Lembaga Keuangan Lainnya. Rajawali Pers.

Kuncoro, M. (2000). Manajemen Perbankan. BPFE Yogyakarta.

Munawir. (2004). Analisis Laporan Kenangan (Cetakan Ke). Liberty Yogyakarta.

Raharjaputra. (2011). Manajemen Keuangan dan Akuntansi. Salemba Empat.

Setiawan, S., Wulansari, P., \& Dewi, R. P. K. (2020). Pengukuran Tingkat Kinerja Keuangan Dan Kinerja Non Keuangan Pada Bank Syariah Di Lima Negara Asia (Studi Kasus Pada Bank Syariah Dengan Aset Tertinggi). Dinamika Akuntansi Keuangan dan Perbankan, 9(1), 69-78.

Subramanyam. (2010). Analisis Laporan Kenangan. Salemba Empat.

Sugiyono. (2016). Metode Penelitian. CV Alfabeta.

Syahyunan. (2013). Manajemen Keuangan (Perencanaan, Analisis dan Pengendalian Keuangan). USU Press.

Thomson, J. (1991). Predicting Bank Failures in the 1980s. Economic Review, 27. 